\title{
Internal structure and composition of a rock glacier in the Andes (upper Choapa valley, Chile) using borehole information and ground-penetrating radar
}

\author{
Sébastien MONNIER, Christophe KINNARD \\ Centro de Estudios Avanzados en Zonas Áridas (CEAZA), La Serena, Chile \\ E-mail: sebastien.monnier@ceaza.cl
}

\begin{abstract}
This study uses boreholes, ground temperature monitoring and ground-penetrating radar (GPR) in order to understand the internal structure and composition of a rock glacier in the upper Choapa valley, northern Chile. The rock glacier is a small valley-side feature, $200 \mathrm{~m}$ long and ranging between 3710 and $3780 \mathrm{~m}$ a.s.l. Two boreholes were drilled down to depths of 20 and $25 \mathrm{~m}$, respectively, using the diamond drillhole technique. An ice-rock mixture was encountered in the boreholes, with heterogeneous ice content averaging $\mathbf{1 5 - 3 0 \%}$. Data from common-midpoint (CMP) and constant-offset (CO) GPR surveys acquired, respectively, near the boreholes and across the whole rock glacier were processed to highlight the internal stratigraphy and variations in the radar-wave velocity. The GPR profiles depict a rock glacier constituted of stacked and generally concordant layers, with a thickness ranging from $10 \mathrm{~m}$ in its upper part to $\sim 30 \mathrm{~m}$ towards its terminus. The CMP analysis highlights radarwave velocities of $0.13-0.16 \mathrm{~m} \mathrm{~ns}^{-1}$ in the first $20 \mathrm{~m}$ of the structure. Larger vertical and lateral velocity variations are highlighted from $\mathrm{CO}$ data, reflecting the heterogeneous composition of the rock glacier and the likely presence of unfrozen water in the structure. Given the average air temperature registered at the site $\left(+0.5^{\circ} \mathrm{C}\right)$, the near-melting-point temperature registered in the boreholes over more than a year and the presence of locally high water content inferred from GPR data, it is thought that the permafrost in the rock glacier is currently degrading.
\end{abstract}

\section{INTRODUCTION}

Rock glaciers are ice-rock mixtures moving downslope and exhibiting striking viscous flow morphology. They are generally regarded as the main geomorphological expression of mountain permafrost (Barsch, 1996; Berthling, 2011), the latter being defined as ground with temperature remaining at or below $0^{\circ} \mathrm{C}$ during at least two consecutive years, irrespective of ice content or texture (Washburn, 1979; Van Everdingen, 2005; Haeberli and others, 2006). Rock glaciers are very common in mid-latitude orogens. This is particularly true in the semi-arid Andes of Chile and Argentina, where they can reach very high concentrations and very large dimensions (Schrott, 1996; Trombotto and others, 1999; Brenning, 2005; Angillieri, 2009; Azócar and Brenning, 2010). The abundance of rock glaciers in the semi-arid Andes potentially makes them the most important ice reservoir, before glaciers; at the scale of some catchments where the density of glaciers is low or null, this is indisputable (Brenning, 2005; Azócar and Brenning, 2010). However, considerable uncertainties remain as to how much ice is stored in rock glaciers at the basin scale, mainly due to a lack of observations of their internal structure and ice content. Studies of rock glaciers in the semi-arid Andes, especially field-based ones, are few compared with other areas of the world such as the intensively studied European Alps. To our knowledge, only two published studies have addressed the problem of the internal structure of rock glaciers in the semiarid Andes (Croce and Milana, 2002; Milana and Güell, 2008). At the same time a considerable amount of mostly unpublished consulting work (e.g. Marangunic, 2010) has brought insights on this topic within the framework of the mining industry. In the mountains of northern Chile, the development of mining activities has indeed been favored by the presence of large amounts of precious metals, with porphyry copper at the forefront (Sillitoe, 2010), and by economic and political factors at global and national levels in recent decades - especially the importance and growth of copper usage in many segments of industry worldwide (ICSG, 2010) and the driving of the Chilean mining sector by the so-called 'Chilean economic model', with a friendly environment for foreign investment (Bastida and others, 2005; Bastida, 2006). Because mining activities may reshape the Earth's surface (e.g. Palmer and others, 2010) and hence affect cryosphere elements, which in semi-arid to arid high mountains may constitute important freshwater reservoirs, the political and scientific interest in the Chilean cryosphere has grown over the past decade (Brenning, 2010). Nevertheless, debates exist around the hydrological importance of rock glaciers (Arenson and Jakob, 2010; Brenning, 2010). This context highlights the need for further research and field measurements on rock glaciers in the semi-arid Andes.

In this paper, we describe and interpret new field data collected on a rock glacier in the upper Choapa valley, Norte Chico region of Chile (between $29^{\circ} 02^{\prime} \mathrm{S}$ and $32^{\circ} 16^{\prime} \mathrm{S}$ ), with the aim of revealing its stratigraphy and estimating its composition. Our approach focuses on the use of groundpenetrating radar (GPR) complemented with borehole drilling and ground temperature monitoring. Over the past decade, many studies have employed GPR in order to describe the stratigraphy of rock glaciers (e.g. Lehmann and Green, 2000; Degenhardt and others, 2003; Hausmann and others, 2007; Monnier and others, 2008; Degenhardt, 2009; Leopold and others, 2011). On the other hand, few studies have used the velocity of radar-wave propagation in rock glaciers. The latter varies significantly both in the lateral and vertical directions, which is likely to reveal valuable 

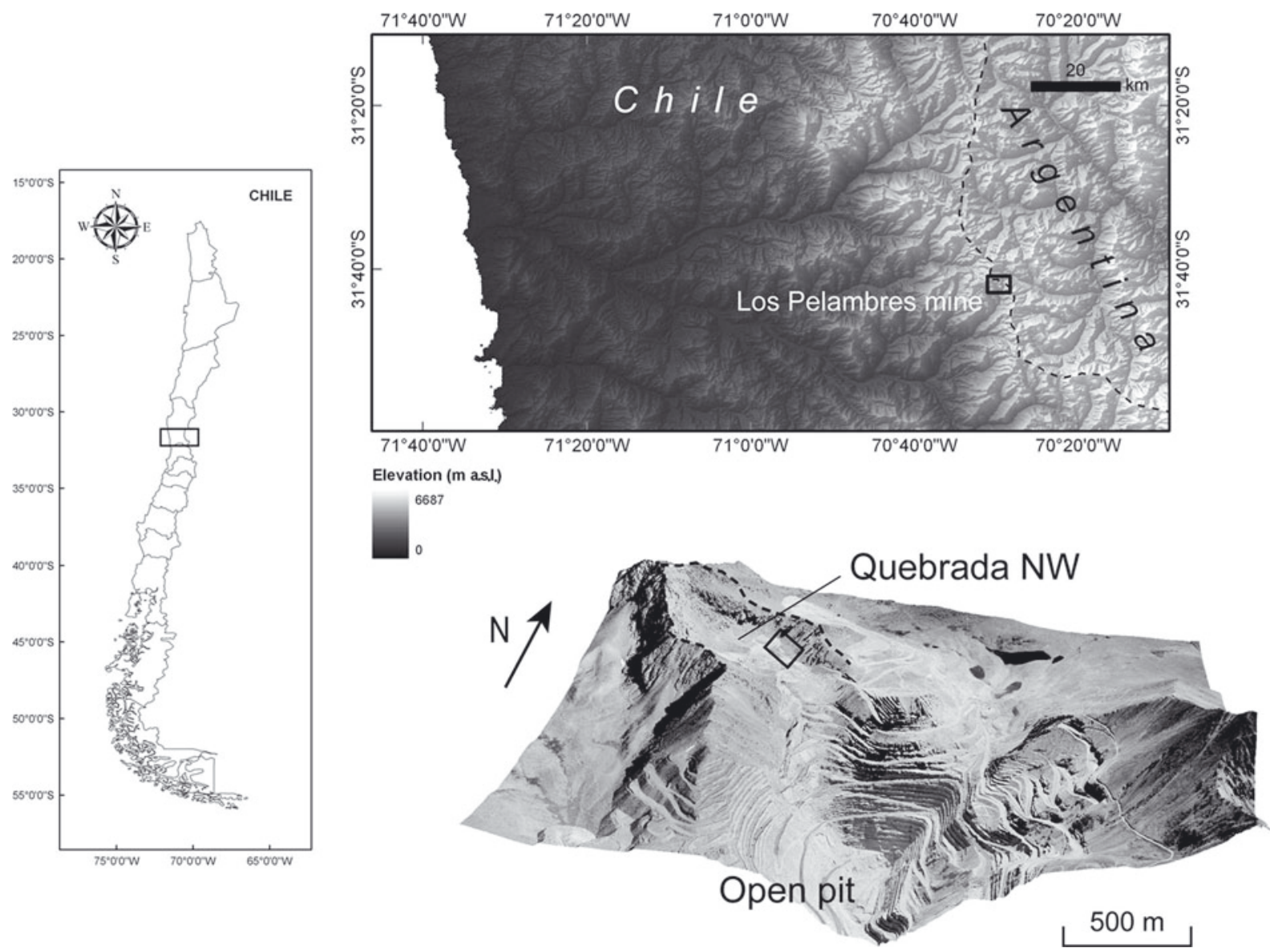

Fig. 1. Location map of the Los Pelambres mine area and Quebrada NW. The studied rock glacier (see Fig. 2) is indicated by a small rectangle in Quebrada NW.

information on the internal composition of rock glaciers (Musil and others, 2006; Monnier and others, 2011). Notably, previous studies have highlighted from geophysical data the presence of liquid water in permafrost (Musil and others, 2006; Maurer and Hauck, 2007; Hauck and others, 2011). Hence our study places emphasis on the characterization and interpretation of the radar-wave velocity in a rock glacier and discusses the influence of unfrozen water within or beneath the rock glacier on the GPR-derived velocity.

\section{STUDY AREA}

The rock glacier investigated is located in a small hanging valley called Quebrada Noroeste (NW) within the Los Pelambres mine area in the upper part of the Choapa valley $\left(31.8^{\circ} \mathrm{S}, 70.5^{\circ} \mathrm{W}\right)$ (Fig. 1). The Los Pelambres mine is an open-pit copper mine with elevations ranging from $\sim 1100$ to $4500 \mathrm{~m}$ a.s. I. The area represents a transition between the Mediterranean climate to the south and the semi-arid steppe climate to the north. The climate of the upper Choapa valley is a highland climate. Using meteorological data from the Chilean Water Service (Dirección General de Agua, DGA), a linear temperature gradient of $-0.73^{\circ} \mathrm{C}(100 \mathrm{~m})^{-1}$ was calculated and resulted in a $0^{\circ} \mathrm{C}$ isotherm located at $\sim 3650 \mathrm{~m}$ a.s.I. In Quebrada NW, a meteorological station installed in 2009 at $3700 \mathrm{ma.s.l}$. by the Los Pelambres Company recorded in 2010 an average air temperature of $+0.5^{\circ} \mathrm{C}$. The nearest precipitation gauge maintained by the DGA (Huintil, $805 \mathrm{~m}$ a.s.l.) registered $207 \mathrm{~mm}$ in 2010, 38\% less than the 1961-90 average of $334 \mathrm{~mm}$. Various consulting studies previously focused on the rock glaciers in Quebrada NW in order to address concerns about the use of this site by the mining company. These studies gave rise to various geomorphological interpretations, from the rejection of permafrost and rock glacier occurrence (DISSAM Sécurité, 2002) to the identification of glacier ice-cored rock glaciers (Geoestudios, 1998); Geoblast (2009) recognized the features in Quebrada NW as rock glaciers and, using geoelectrical measurements, made the hypothesis of permafrost occurrence. Apart from these consulting studies, Azócar and Brenning (2008) and Brenning and Azócar (2010) inventoried rock glaciers in Quebrada NW from aerial photograph and satellite imagery interpretation. They emphasized the role that these rock glaciers may play as reservoirs and suppliers of fresh water and the damage that these landforms may suffer, or have already suffered, from nearby mining activities.

In Quebrada NW (Fig. 2), the most prominent natural morphological feature is a set of small $(<350 \mathrm{~m})$ coalescent valley-side rock glaciers at the foot of a southwest-facing andesitic crest. Aerial photographs from the end of the 1990s, before any mining intervention took place, allow identification of seven rock glacier units at the foot of the southwest-facing crest. The rock glaciers represent an area of $0.359 \mathrm{~km}^{2}$. The infilling of Quebrada NW with extraction mineral residues began in 2002-03, but was later stopped in anticipation of further permafrost studies, so that a portion (65\% of the original area) of the rock glaciers identified in the late 1990s has been covered and is no longer visible. In 2010 and 2011, we studied the rock glacier identified as 


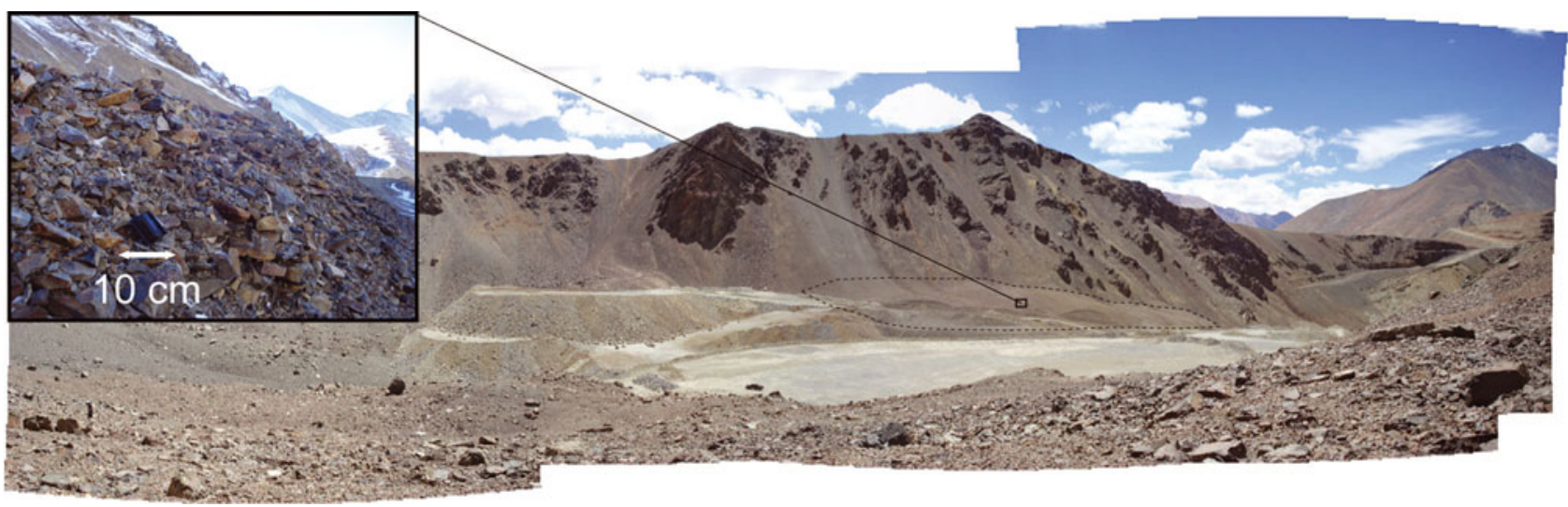

Fig. 2. Quebrada NW viewed from the northwest (in the main picture south is to the right). The inset photograph shows the materials encountered in the first few decimeters below the surface (the pocket camera case gives the scale). The study area is depicted with a dashed line.

\#5 and the upper lateral part of the one identified as \#4 (Figs 2 and 3). These represent the most intact landforms that remain visible at the site, i.e. they were the least disturbed by mining operations. The elevation range of the surveyed area is $3710-3780 \mathrm{~m}$ a.s.I. Rock glacier \#5 is a small, $270 \mathrm{~m}$ wide and $200 \mathrm{~m}$ long valley-side landform. The original (undisturbed) surface of the rock glacier is quite smooth without noticeable ridges and furrows. However, a clear and steep front is noticeable on the satellite images recorded before burial of the distal part by extraction residues and is still perceptible in the artificial morphology. Using a highresolution $(2 \mathrm{~m})$ digital elevation model (DEM) of the area derived from aerial photographs taken in 2009, the original height of the front was estimated to be $\sim 10 \mathrm{~m}$. On the currently intact parts of the surface, the material is coarse, consisting of gravels, cobbles and small $(<30 \mathrm{~cm})$ boulders (Fig. 2). Monitoring of surface movement at five locations on rock glaciers \#4 and \#5 was carried out by topographers from the Los Pelambres Company between March 2010 and
March 2012 and showed horizontal displacements between 13 and $50 \mathrm{~cm} \mathrm{a}^{-1}$ (CEAZO, 2012).

\section{METHODS}

\subsection{Core drillings}

Two boreholes (DDH2010-1 and DDH2010-2) of 25 and $20 \mathrm{~m}$ depth, respectively, were drilled in the intact part of the rock glacier (Fig. 3). The drilling operation took place at the end of the summer (April) of 2010 without any snow cover on the surface. In most previous studies refrigerated air-flush drilling technology had been used (Haeberli and others, 1988; Arenson, 2002; Arenson and Springman, 2005); however, in this study we applied the diamond drillhole (DDH) technique (Barsch and others, 1979) due to its availability on the site for use in geological exploration. A $96 \mathrm{~cm} / 63.5 \mathrm{~cm}$ inner/outer diameter drill head was used. The limit of such a technique lies in the warming generated in

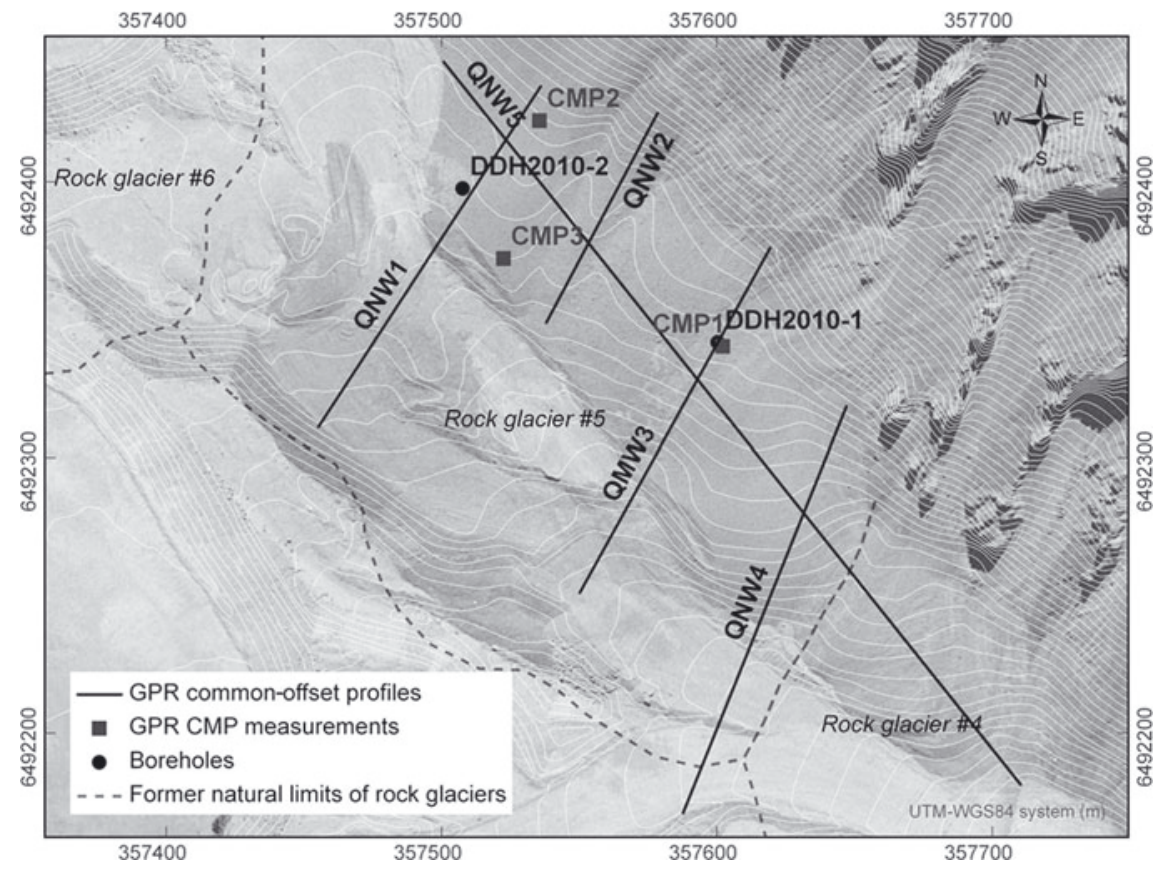

Fig. 3. Location of the GPR common-midpoint and constant-offset profiles and boreholes on the studied rock glacier \#5 and upper margin of rock glacier \#4, Quebrada NW. The map is a 2009 orthophoto from which the elevation contours were also derived. 
the borehole by the rotation of the diamond head; although cooling is maintained by the injection of cold water, losses of core samples are bound to occur. This use of water also prevents the determination of volumetric ice content by the gravimetric method using known densities (Arenson and Springman, 2005). Considering that rock glaciers have been drilled only on very rare occasions (see Haeberli and others, 2006), this opportunistic technique was still considered valuable to visually examine the inner part of the rock glacier and to provide general ground-truthing for the GPR results. During drilling of the hole, the recovery rate (the ratio between the retrieved sample length and the total length drilled) was recorded. The samples were described according to visible grain size and ice filling. Since the DDH technique disturbs and wets the structure we did not weigh the samples. The temperature of the samples was measured on site immediately after their recovery from the borehole using a manual digital thermometer. The ice content was estimated visually at depth intervals of $10-40 \mathrm{~cm}$ depending on the complexity of the stratigraphy. The varying recovery rate of the sample cores was then used to estimate the potential minimum and maximum ice content. As the type of material lost during the coring is unknown, we considered that the lost core fraction may have been composed of pure debris or pure ice; however, it is probable that ice-poor wet materials are more likely to be destroyed and lost due to their lower cohesive strength.

\subsection{Ground temperature monitoring}

The DDH2010-1 borehole was equipped with a $25 \mathrm{~m}$ long 12-thermistor (Lakewood Inc.) string with an accuracy of $\pm 0.2^{\circ} \mathrm{C}$. Thermistors were spread between the surface $(0 \mathrm{~m})$ and at successive depth intervals of $2 \mathrm{~m}$ between -1 and $-17 \mathrm{~m}$ and of $4 \mathrm{~m}$ between -17 and $-25 \mathrm{~m}$. The borehole was backfilled with sand and sealed with bentonite at the surface to prevent water percolation. A data logger was connected to the string and programmed to record borehole temperatures every 2 hours. In the DDH2010-2 borehole an $18 \mathrm{~m}$ long five-thermistor string with an accuracy of $\pm 0.2^{\circ} \mathrm{C}$, without a data logger, was placed for punctual measurements.

\subsection{Ground-penetrating radar}

In April 2010, we used a pulseEKKO Pro DVL (Sensors \& Software Inc.) GPR system mounted with unshielded $50 \mathrm{MHz}$ antennas in order to obtain data describing the subsurface of rock glacier \#5 in Quebrada NW. We performed (Fig. 3): (1) three common-midpoint (CMP) surveys near the boreholes using a step size of $0.4 \mathrm{~m}$; and (2) five constant-offset (CO) profiles (four longitudinal profiles of $\sim 150 \mathrm{~m}$ and one $350 \mathrm{~m}$ long transverse profile) throughout the intact and intervened parts of the rock glacier using an antenna separation of $2 \mathrm{~m}$ and a step size of $0.5 \mathrm{~m}$. Whereas the CMP1 survey was performed at the exact location of DDH2010-1 before drilling of the borehole, the CMP2 and CMP3 surveys were performed $50 \mathrm{~m}$ northwest and $35 \mathrm{~m}$ southeast of DDH2010-2, respectively, because the borehole had already been drilled and the surface disrupted by the drilling platform. For the whole survey, each collected trace was the results of 16 stacks in order to increase the signal-to-noise ratio. Topographic data were integrated into the GPR survey using a handheld GPS for planar positioning and elevation values from the pre-existing 2009 high-resolution DEM. An automatic high-pass filter (dewow filter) was applied to the GPR data to remove the very low-frequency component. Following common procedures (Eisen and others, 2002; Annan, 2003) semblance analysis of the CMP data was performed in order to obtain a vertical profile of the normal moveout (NMO) velocity. Then, according to the main changes seen in the borehole stratigraphy, interval velocities were calculated using the Dix formula (Dix, 1955). The four longitudinal CO profiles were migrated with a Stolt (1978) migration using a constant velocity $\left(0.13 \mathrm{~m} \mathrm{~ns}^{-1}\right)$ derived from consideration of both the $\mathrm{CMP}$ results and the fitting of some diffraction hyperbolas in the unmigrated $\mathrm{CO}$ data. The data from the transverse profile (QNW5) allowed the following advanced processing steps to derive the distribution of the radar-wave velocity. The large number of diffraction hyperbolae in the data was used for calculating root-mean-square (rms) velocities using the hyperbola-fitting method. The latter technique has been described by Brandt and others (2007), Bradford and others (2009) and Jol (2009). Jol (2009) reported errors of $\pm 10 \%$ associated with the technique. To reduce the errors, velocity measurements were carefully repeated several times on each hyperbola, so that the maximum error on rms velocities is estimated to be $<5 \%$. Subsequently, the distribution of rms velocities was used for migration of the profile using a twodimensional (2-D) Kirchhoff migration (Yilmaz and Doherty, 2001). When hyperbolae were found to be approximately aligned vertically along the profile, which was frequently the case, the Dix formula (Dix, 1955) was used to convert the rms velocities into a vertical profile of interval velocities. Maximum errors on calculated interval velocities were computed considering the maximum $\pm 5 \%$ error on rms velocities. The interval velocities were used for the time-todepth conversion of the profile. Finally, static elevation corrections were applied to all GPR profiles using the topographic data, and profiles were further visually enhanced using automatic gain control (AGC) gain with a time window of $60 \mathrm{~ns}$.

\section{RESULTS}

\subsection{Borehole stratigraphy}

Figure 4 shows the observed stratigraphy at the boreholes DDH2010-1 and DDH2010-2. In the DDH2010-1 borehole, the first $7 \mathrm{~m}$ are devoid of ground ice and exhibited positive temperatures at the moment of their retrieval. The materials are predominantly sand with gravels $(0-5 \mathrm{~m}$ deep) and then angular gravels with a few sand matrices (5-7 $\mathrm{m}$ deep). Below $7 \mathrm{~m}$, the materials are frozen. The occurrence of ground ice is heterogeneous. Between 7 and $10 \mathrm{~m}$ depth, there is an alternation of layers with excess pore ice, layers with unsaturated pore ice and even two very thin $(10 \mathrm{~cm})$ layers of pure ice. Below $10 \mathrm{~m}$, sediments with unsaturated pore ice predominate, with the occasional occurrence of thin layers with excess pore ice. The sediment size in the DDH2010-2 borehole is nearly constant throughout its length, consisting of angular gravels with a few sand matrices. The top unfrozen layer is thinner than in the first borehole $(5 \mathrm{~m})$. Below $5 \mathrm{~m}$ the materials are frozen, again with heterogeneous occurrence of ground ice. Between 5 and $\sim 12 \mathrm{~m}$, unsaturated pore ice predominates, though two $\sim 50 \mathrm{~cm}$ thick layers with excess pore ice and one $20 \mathrm{~cm}$ thick layer of pure ice are encountered. Below $\sim 12 \mathrm{~m}$ and down to the bottom of the borehole, the frequency of layers with excess pore ice increases, alternating with layers of 


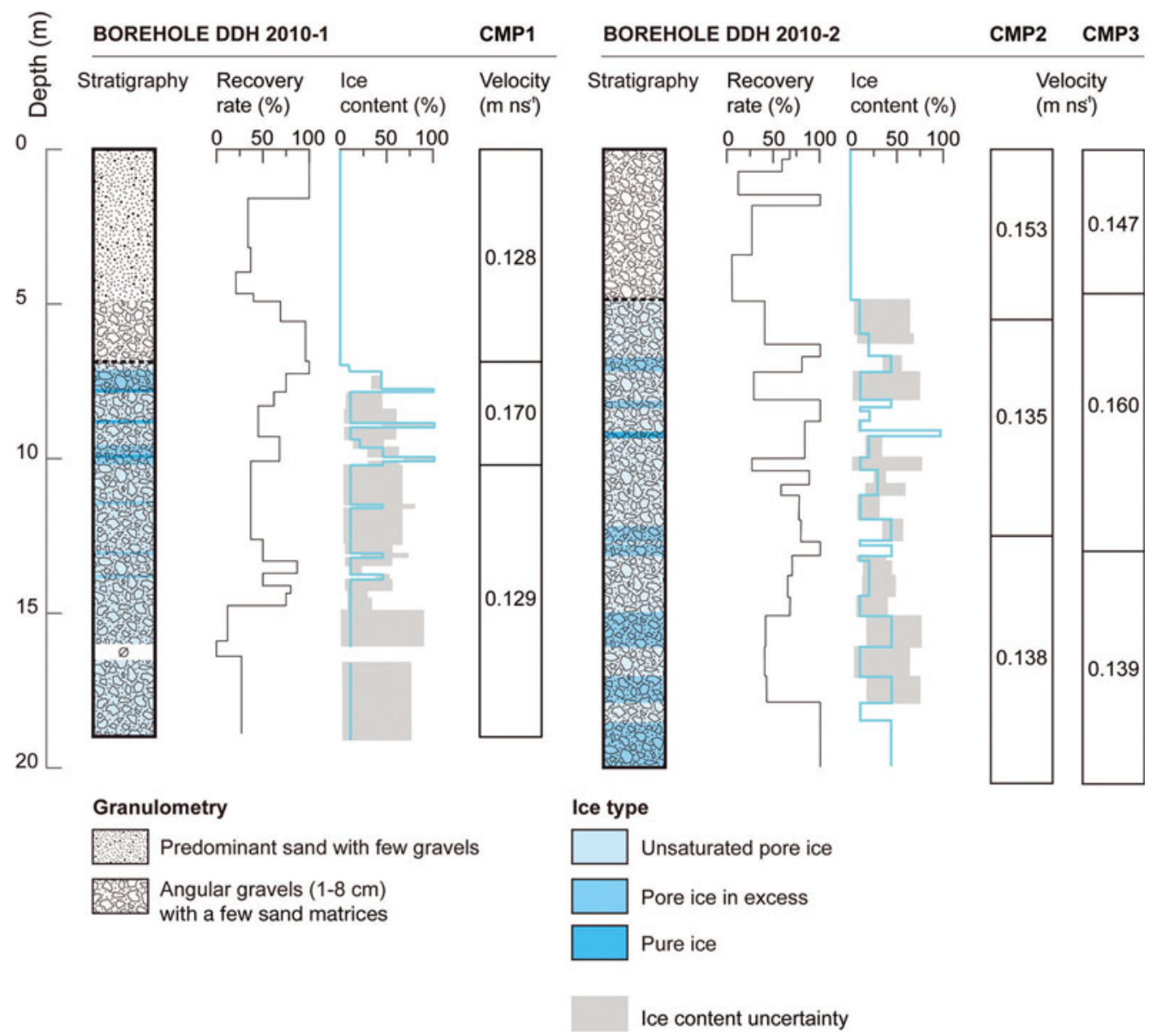

Fig. 4. Stratigraphy, core recovery rate, ice content in the two boreholes and corresponding radar-wave velocity profiles obtained from the analysis of the CMP data; the main stratigraphic discontinuities in the boreholes were used to constrain the conversion from NMO velocities to interval velocities. The ice content uncertainty is bounded by the potential minimum and maximum ice contents, corresponding to losses of pure debris and pure ice, respectively.

unsaturated pore ice. The lowest $6 \mathrm{~m}$ of the DDH2010-1 borehole are not presented here because the null recovery rate or the very bad state of the samples did not provide reliable data. In neither borehole was the bedrock reached.

In both cores the visual ice content is $<10 \%$ in unsaturated frozen sediments and $\sim 40 \%$ in layers with excess pore ice. In the DDH2010-1 borehole the average recovery rate in the first $19 \mathrm{~m}$ is $51 \%$ ( $44 \%$ in the frozen parts below the superficial unfrozen layer), with the lowest recovery rates occurring below $15 \mathrm{~m}(>30 \%)$. In the DDH2010-2 borehole the average recovery rate is $57 \%$
(67\% in the frozen parts), with the lowest rates in the unfrozen superficial layer $(>10 \%)$ and at $15-17 \mathrm{~m}$ depths $(>45 \%)$. The low recovery rates of some of the cores evidently question the nature of the lost samples. Assuming that the lost core material could represent either pure ice or pure debris leads to a considerable uncertainty range around the average ice content calculated from the recovered samples, especially in the deepest part of the DDH2010-1 borehole (Fig. 4). Still, the uncertainty envelope around the estimated ice content profile shows significant vertical heterogeneity. From the recovered cores the calculated

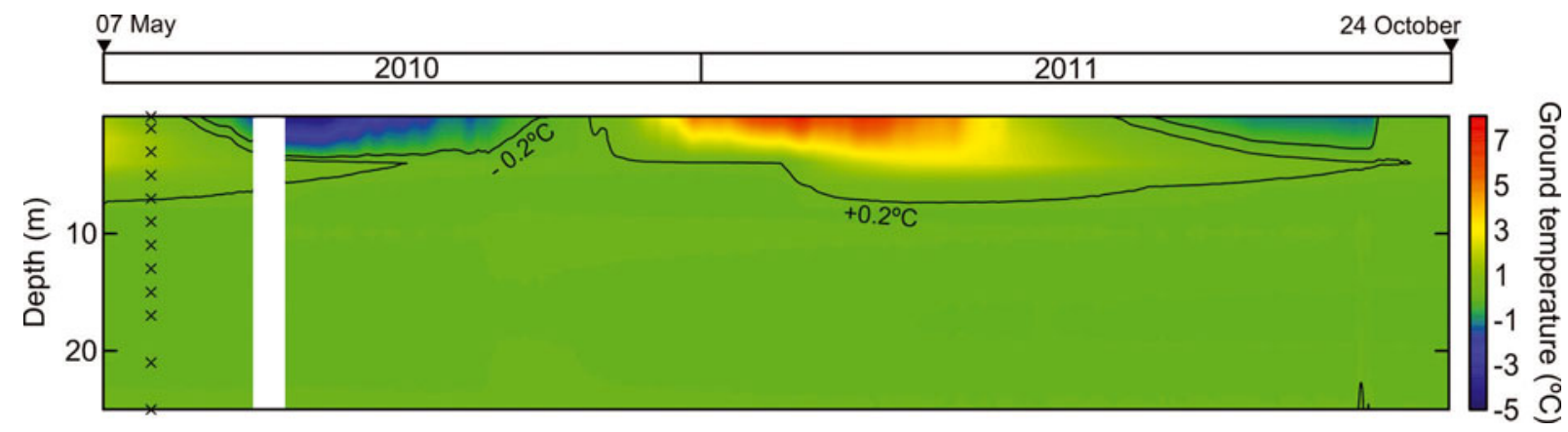

Fig. 5. Ground temperature regime interpolated from the thermistor data between 1 and $25 \mathrm{~m}$ depth in the DDH2010-1 borehole. The black crosses on the left axis show the location of the thermistors. The $-0.2^{\circ} \mathrm{C}$ and $+0.2^{\circ} \mathrm{C}$ isotherms are indicated in black as they represent the confidence interval bound around the $0^{\circ} \mathrm{C}$ isotherm. 


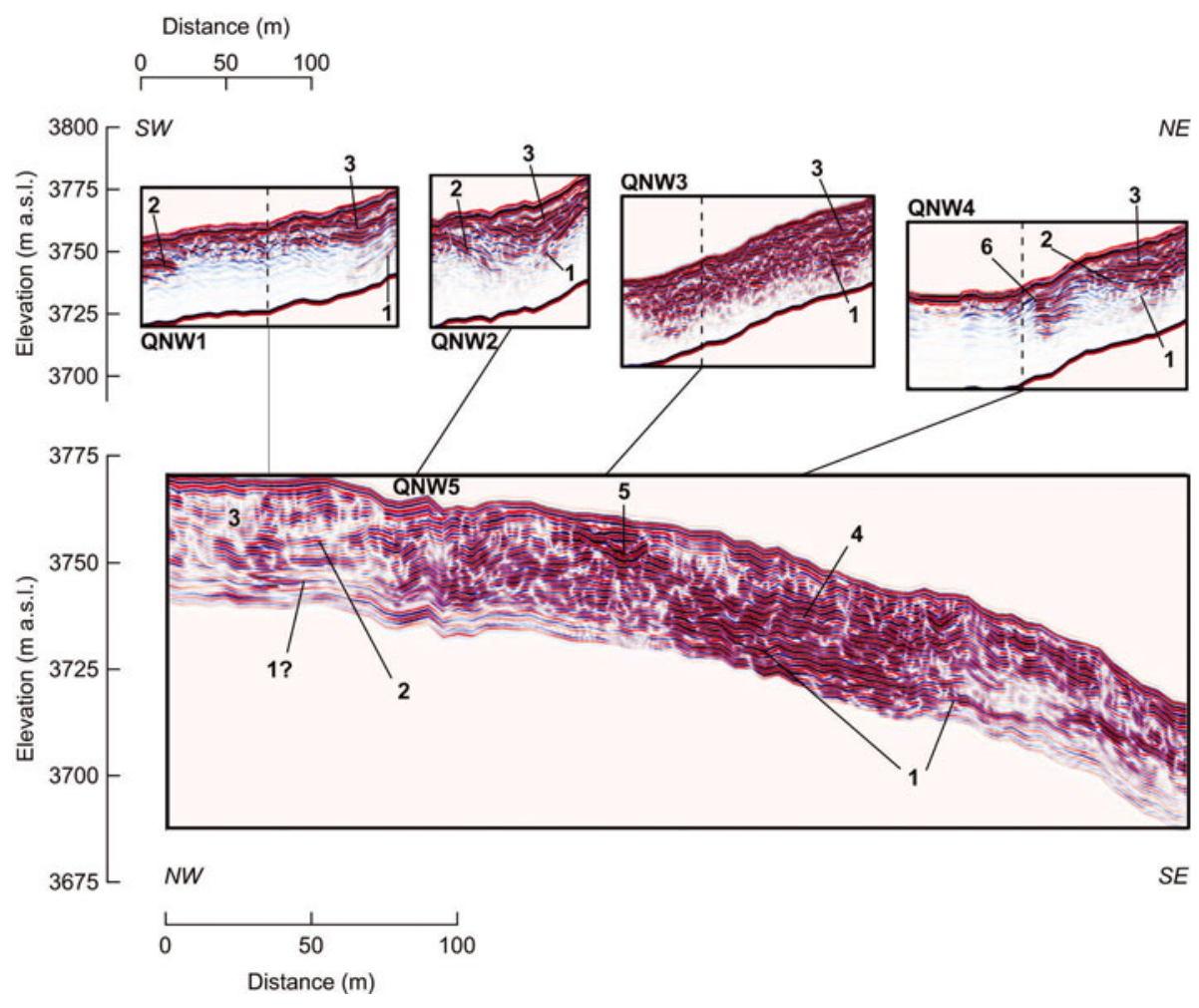

Fig. 6. Migrated GPR profiles. All profiles were enhanced with AGC and compensated for elevation. The dashed lines indicate the limits between the intervened (southwest) and intact (northeast) parts of the rock glacier. The position of the longitudinal profiles (QNW1-QNW4) is reported onto the transversal profile (QNW5). See Figure 3 for the exact positions of the profiles on the rock glacier. Specific GPR stratigraphic features are indicated by numbers: 1 . basal bounding reflectors; 2 . internal bounding reflectors; 3 . concordant and stacked reflectors; 4. undulating and toplapping events; 5. prominent V-shaped reflector (at $x=155 \mathrm{~m}$ ); 6 . artificial structures of reflectors (folded structures). Note that for commodity the horizontal scale differs between the longitudinal profiles and the transversal profiles.

average ice content in the frozen portions of the DDH20101 borehole is $16 \%$ (uncertainty interval 9-63\%). The average ice content in the $20 \mathrm{~m}$ of the DDH2010-2 borehole is $27 \%$ (uncertainty interval 19-52\%). The estimated ice content was linearly regressed onto the core recovery rate to examine a possible causative link between the two variables. Coefficients of determination $\left(r^{2}\right)$ of 0.08 and 0.05 are found for DDH2010-1 and DDH2010-2, respectively, showing that the rate of core loss does not significantly explain the vertical variations in estimated ice content.

\subsection{Ground temperatures}

The monitoring of the ground temperature in borehole DDH2010-1 confirms the existence of a 5-7 m thick seasonally unfrozen superficial layer (active layer) (Fig. 5). Below this, the ground is constantly frozen and, despite the lack of a few months of measurements needed to fulfill the accepted definition, the rock glacier can be considered as a permafrost feature. However, the thermal state of the permafrost appears singular since all temperature probes between 7 and $25 \mathrm{~m}$ depth remain at $0^{\circ} \mathrm{C}$ year-round (taking into account the $\pm 0.2^{\circ} \mathrm{C}$ accuracy of the probes). This phenomenon is well known at the seasonal timescale as the 'zero curtain effect' (Outcalt and others, 1990; Hanson and Hoelzle, 2004). The zero curtain effect is explained either by the release of latent heat during the change of phase from water to ice or by the absorption of latent heat during the change of phase from ice to water. Moreover, the temperature measurements performed episodically (three times in the year) in the DDH2010-2 borehole (not shown) confirmed the values measured in the DDH2010-1 borehole.

\subsection{Ground-penetrating radar}

\subsubsection{GPR stratigraphy}

The migration of the GPR profiles, using a constant velocity for the QNW1-QNW4 profiles and a 2-D velocity distribution for the QNW5 profile, have collapsed the hyperbolae and considerably improved the visualization of GPR reflections, allowing for a detailed view of the rock glacier GPR stratigraphy (Fig. 6). On the whole, the internal structure shows vertical heterogeneity but also a certain degree of lateral continuity of the most prominent reflectors. We first examine the longitudinal profiles (QNW1-QNW4). In the upper parts of these profiles, bounding and strongly downdipping reflectors are encountered between 10 and 25-30 m depths; we call these reflectors 'basal' because they very likely represent the interface between the rock glacier and the underlying deposit or bedrock. The basal reflector is particularly conspicuous in the median part of the QNW2 profile. Over these basal reflectors, the overall internal stratigraphy of the rock glacier is made of rather smooth and superimposed reflectors, onlapping onto the basal one, concordant with one another and synclinally disposed in the case of QNW1 and QNW2 (i.e. in the northwestern part of the rock glacier). In areas affected by mining operations, the imaging of the GPR data is rather poor (QNW1) or null (QNW4). In the third longitudinal profile (QNW3), the GPR stratigraphy in the intervened part appears quite disorganized with rather small reflectors. A neat folded structure is also observed at the lower end of the intact portion of QNW4. In the transversal direction (profile QNW5), the GPR stratigraphy is somewhat more complex. Whereas concordant and laterally continuous layers predominate, undulating and 

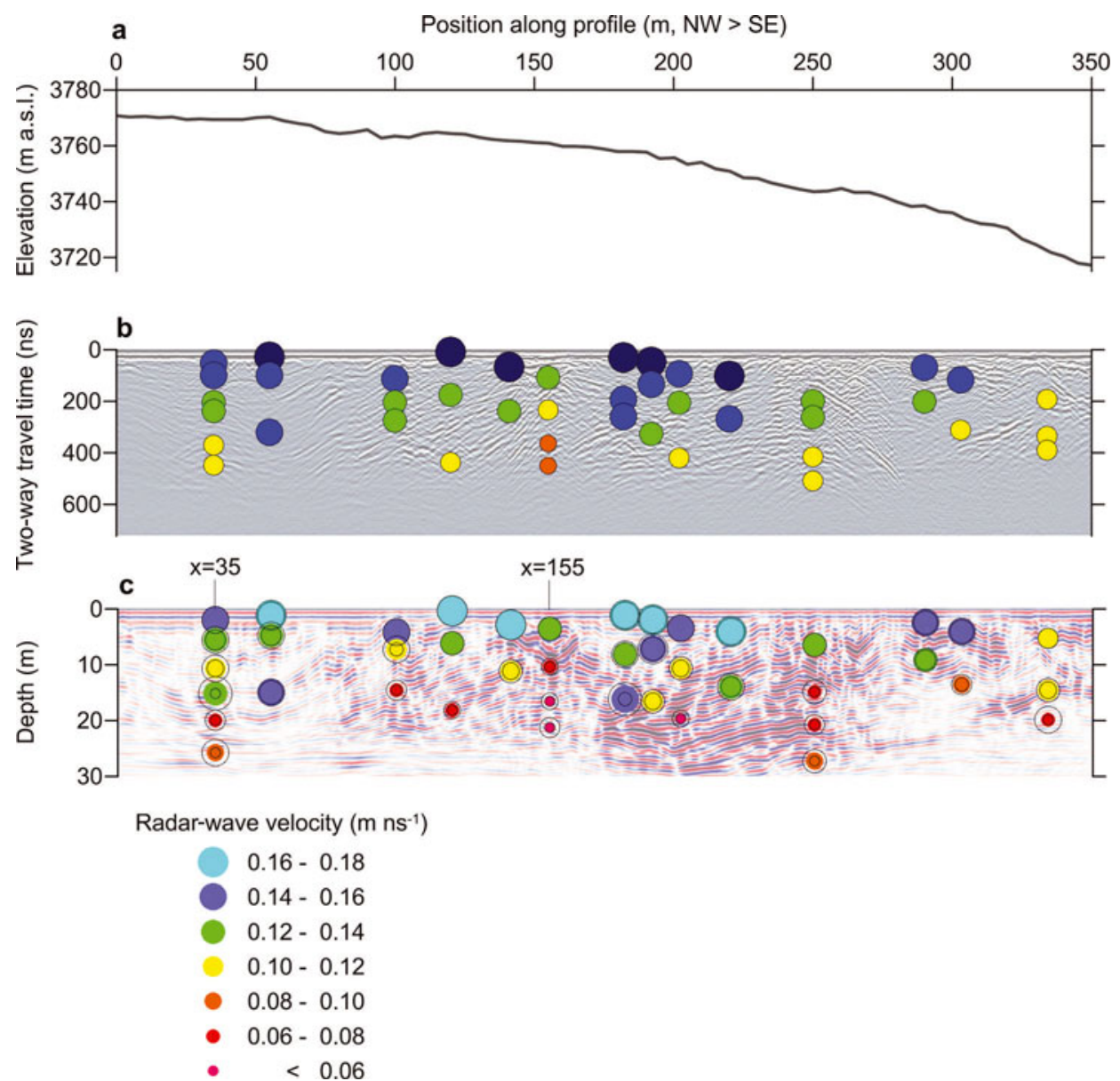

Fig. 7. Calculation of interval velocities from rms velocities measured along hyperbolae in the radargram of the transversal profile (QNW5): (a) topography; (b) rms velocities; (c) interval velocities. The maximum error bound around calculated values is indicated by the inner and outer black circles. The positions $x=35 \mathrm{~m}$, close to CMP2 and CMP3, and $x=155 \mathrm{~m}$, close to CMP1, are indicated.

overlapping reflectors are also identified. A basal bounding reflector can be traced quite neatly over the lower (southeast) part of the profile at $\sim 25 \mathrm{~m}$ depth, but fades toward the northwest end.

\subsubsection{Radar-wave velocity}

The vertical profiles of the radar-wave velocity obtained from the CMP data near the boreholes exhibit noticeable variations (Fig. 4). In the top few meters corresponding to the unfrozen active layer, the velocity is typically $\sim 0.15 \mathrm{~m} \mathrm{~ns}^{-1}$ at CMP2 and CMP3 (materials in nearby DHH2010-2 are gravels) and slightly lower $\left(\sim 0.13 \mathrm{~m} \mathrm{~ns}^{-1}\right)$ at CMP1 (materials in nearby DDH2010-1 are sand with gravels). At CMP1, the velocity increases to $0.17 \mathrm{~m} \mathrm{~ns}^{-1}$ between 7 and $10 \mathrm{~m}$, which corresponds to the concentrated ice-rich layers found in DDH2010-1; in the lower part of the vertical profile $(<10 \mathrm{~m})$, the velocity is $\sim 0.13 \mathrm{~m} \mathrm{~ns}^{-1}$. At CMP2, below the top layer, the velocity is nearly constant with values of 0.135$0.138 \mathrm{~m} \mathrm{~ns}^{-1}$, while at CMP3 a layer with a velocity of $0.16 \mathrm{~m} \mathrm{~ns}^{-1}$ is found between 5 and $13 \mathrm{~m}$ before the velocity decreases to $\sim 0.14 \mathrm{~m} \mathrm{~ns}^{-1}$ below. The various velocity profiles obtained from the $\mathrm{CO}$ data along the transversal profile (QNW5) display significant lateral and vertical variations (Fig. 7). In the first few meters of the structure, in the active layer, the velocity is $0.15-0.17 \mathrm{~m} \mathrm{~ns}^{-1}$. Below this, in the permafrost layer, values in the interval 0.12 $0.16 \mathrm{~m} \mathrm{~ns}^{-1}$ are frequent, in agreement with the velocity profiles from the CMP surveys. However, deeper in the rock glacier (below 15-20 m) and generally close to the basal bounding reflector, but also at some locations closer to the surface, the velocity can decrease well below $0.10 \mathrm{~m} \mathrm{~ns}^{-1}$. On the whole, the velocity tends to decrease toward the southeast (downslope) end of the profile. The maximum error bound around interval velocities (Fig. 7c) is greater for points with lower rms values (Fig. 7b) and with nearby hyperbolas, which points to the sensitivity of the method to the time separation between hyperbolas and the need for careful rms velocity estimation. As rms velocities were calculated several times at each point, calculated values are considered to be reliable.

It is worth observing in detail the CO-data-derived velocity profiles at the profile locations closest to the CMP surveys (Fig. 8). At $155 \mathrm{~m}$ (close to CMP1), the CO velocity is $0.13 \mathrm{~m} \mathrm{~ns}^{-1}$ in the first $7 \mathrm{~m}$, in agreement with CMP1, but below this the $\mathrm{CO}$ velocity decreases dramatically to values between 0.05 and $0.08 \mathrm{~m} \mathrm{~ns}^{-1}$, hence strongly diverging from the CMP1 velocity profile. This decrease in the CO velocity occurs exactly below a peculiar $\mathrm{V}$-shaped stratigraphic feature ending at $7 \mathrm{~m}$ depth (visible in Figs 6-8). On the other hand, close to the DDH2010-2 borehole the CO velocity profile obtained from the QNW5 profile is in better agreement with the nearby CMP2 profile; however, an important decrease in the $\mathrm{CO}$ velocity down to $0.07 \mathrm{~m} \mathrm{~ns}^{-1}$ is observed below $17 \mathrm{~m}$ depth, which is not apparent in CMP2. These discrepancies between velocity estimates from $\mathrm{CMP}$ and $\mathrm{CO}$ data must be seen in the light of: (1) the 
$\mathrm{x}=35 \mathrm{~m}$ (close to CMP2 and CMP3) Position $(\mathrm{m})$ Interval velocity $\left(\mathrm{m} \mathrm{ns}^{-1}\right)$

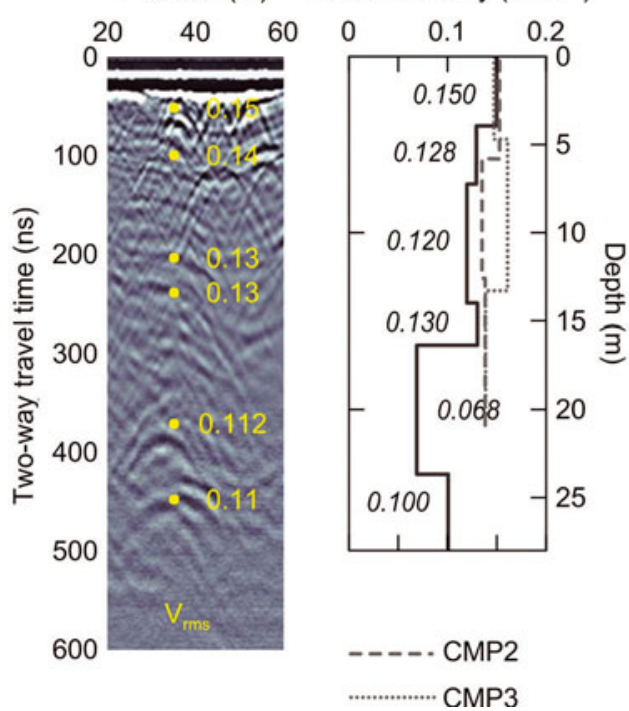

$\mathrm{x}=155 \mathrm{~m}$ (close to CMP1) Position (m) Interval velocity $\left(\mathrm{m} \mathrm{ns}^{-1}\right)$

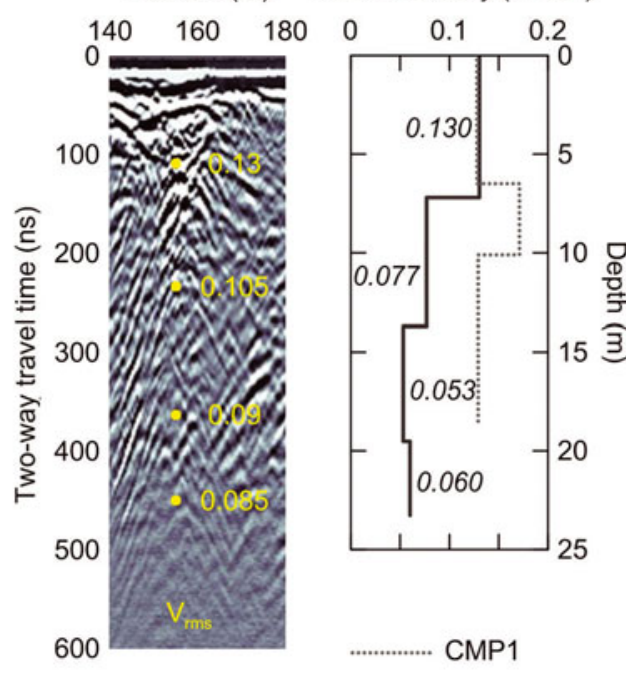

Fig. 8. Detailed velocity profiles from Figure 7 at locations $x=35 \mathrm{~m}$ and $x=155 \mathrm{~m}$ corresponding to CMP2/CMP3 and CMP1, respectively.

potentially strong lateral variations in electromagnetic characteristics in a complex medium such as a rock glacier (see Section 5); and (2) the potential overestimation of the interval velocity that can occur in CMP velocity analysis when strong vertical velocity gradients exist (Bradford, 2008).

\section{DISCUSSION}

\subsection{Uncertainties of the core samples}

The studied rock glacier contains ice but in a proportion that is disputable from the borehole evidence because of the limitations of the coring technique employed. Whereas both extreme situations of losses of pure ice and pure debris were used to constrain the minimum and maximum possible ice contents, respectively, it remains difficult to estimate with more precision the ice content at the borehole locations. The absence of a significant positive correlation between the recovery rate and the estimated ice content suggests that low recovery rates do not correspond to losses of pure ice. Moreover, the cohesion of materials in permafrost conditions is exponentially and positively correlated with their ice content (Arenson, 2002). Therefore, it is plausible that the lost core sections correspond to ice-poor and wet materials with poor cohesive strength. Hence in the reconstruction of the potential maximum ice content (Fig. 4), the extreme values (>70-80\%) obtained at some depths are probably unrealistic. As such, whereas the uncertainty interval around the average ice content in the permafrost is 9-63\% (borehole DDH2010-1) and 19-52\% (borehole DDH2010-2), the actual average ice content is likely to be closer to the average value calculated from observations (16\% for DDH2010-1, $27 \%$ for DDH2010-2). On the whole, apart from the rare and very thin layers of pure ice, our data point toward the presence of a rock-ice mixture with a low ice content ( 15-30\%) and with significantly vertical heterogeneity.

\subsection{Radar-wave velocity}

The main finding regarding the radar-wave velocity is its lateral and vertical variability, particularly apparent in the analysis of the transversal CO profile (QNW5). These variations constitute a potentially valuable source of information on the materials inside the rock glacier and their significance must be explored. The radar-wave velocity is related to the relative dielectric permittivity $\varepsilon$ by the relation

$$
v=\frac{c}{\sqrt{\varepsilon}}
$$

where $c$ is the speed of light in a vacuum $\left(0.299 \mathrm{~m} \mathrm{~ns}^{-1}\right)$. In a complex medium such as a rock glacier, which is composed of debris, ice, unfrozen water and air (Arenson, 2002; Hauck and others, 2011), the bulk permittivity of the medium can be modeled using a four-phase mixture model of the form (Zakri and others, 1998; Bittelli and others, 2004)

$$
\varepsilon^{\alpha}=\theta_{\mathrm{r}} \varepsilon_{\mathrm{r}}^{\alpha}+\theta_{\mathrm{i}} \varepsilon_{\mathrm{i}}^{\alpha}+\theta_{\mathrm{w}} \varepsilon_{\mathrm{w}}^{\alpha}+\theta_{\mathrm{a}} \varepsilon_{\mathrm{a}}^{\alpha}
$$

where $\theta_{\mathrm{r}}, \theta_{\mathrm{i}}, \theta_{\mathrm{w}}$ and $\theta_{\mathrm{a}}$ are the volumetric fractions of rock debris, ice, water and air, respectively; $\varepsilon_{\mathrm{r}}, \varepsilon_{\mathrm{i}}, \varepsilon_{\mathrm{w}}$ and $\varepsilon_{\mathrm{a}}$ are the relative dielectric permittivities for rock debris, ice, water and air, respectively; and $\alpha$ is a factor that, although frequently considered as empirical, has a physical meaning depending on the arrangement of the particles in the medium (Zakri and others, 1998) and is taken as 0.5 when considering a random arrangement of the particles (e.g. Bittelli and others, 2004), which comes to what is referred to as the complex refractive index model (CRIM) proposed by Birchak and others (1974).

For understanding the velocity variations in the studied rock glacier, the components with the lowest (air $=1$ ) and the highest permittivity (water $=88$ when the temperature is close to the melting point; Thomson and others, 2012) are of special interest; ice and andesitic debris have permittivities of 3.2 and 3.5-5.0 (Campbell and Ulrichs, 1969; Abid, 2005), respectively. According to the rare measurements performed in samples retrieved from rock glacier boreholes (Arenson, 2002; Arenson and Springman, 2005), the air content must be low, $<10-15 \%$. The water content, on the other hand, can be estimated directly from the bulk permittivity using the common Topp formula (Topp and others, 1980). The latter formula is valid over a permittivity range of 3-40 and has been confirmed for a very large variety of cases (Noborio, 2001) including frozen soils with 


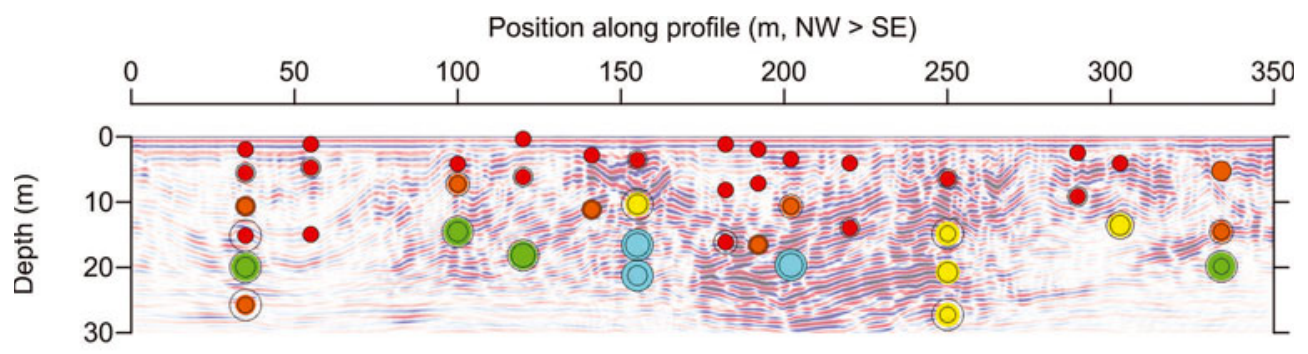
Water fraction
- $0.00-0.10$
- $0.10-0.20$
$0.20-0.30$
$0.30-0.40$
$0.40-0.50$

Fig. 9. Water fractions along the transversal profile (QNW5) estimated from the application of the Topp formula to calculated interval velocities (see Fig. 7). The maximum error bound around water content values, which arises from maximum errors on calculated interval velocities, is indicated by the inner and outer black circles.

ice (with an uncertainty of $\pm 0.025 \mathrm{~cm}^{3} \mathrm{~cm}^{-3}$; Smith and Patterson, 1984) and gravelly soils (Drungil and others, 1989). Its applicability in our case is reinforced by the absence of clay (confirmed by the observations in the boreholes) and the consolidated state of the rock glacier as a permafrost feature. The application of the Topp formula to the interval velocities of transversal profile QNW5 yields water content values typically ranging between $0 \%$ and $20 \%$, but reaching as high as $46 \%$ (Fig. 9). High water contents (>20\%) generally occur below depths of 15-20 m. At $35 \mathrm{~m}$, high water content is visible at the bottom of a typical syncline structure, where it is plausible that water convergence occurs. In two other cases (at 155 and $250 \mathrm{~m}$ along the profile, respectively), high water contents concentrate along a vertical segment. As the porosity of the dry sediments (mostly gravels) of the rock glacier must be between $25 \%$ and $40 \%$ (Delleur, 1999), many of the water content values calculated here imply a saturation of the materials. Some of the highest values may be partly explained by the propagation of the initial uncertainty on rms velocity determination to the interval velocity and water content calculations (Fig. 9). However, despite the possible errors, the data still suggest the occurrence of punctually high water contents, and values higher than $40 \%$, in excess of porosity, must be explained by macro-porosity features such as cracks or channels. These are quite plausible at the base of the rock glacier and, in cases when the velocity drops downward repeatedly such as seen at $155 \mathrm{~m}$ along the profile (Figs 6-9), imply the presence of water-filled cracks/ conduits in the permafrost akin to those seen in glaciers and buried ice deposits (e.g. Moorman, 2005). The presence of concentrated water in such zones is supported by the prominent $\mathrm{V}$-shaped reflector previously described at $155 \mathrm{~m}$ and which may be interpreted as a funnel-type feature reaching down to $10 \mathrm{~m}$ depth, perhaps linked to a crack below in which the water penetrates. Moreover, in the unmigrated data (Fig. 8), the column of hyperbolas and intercrossed reflectors at this position is reminiscent of the features created by crevasses in glaciers (Moore and others, 1999). High water contents are not necessarily incompatible with the presence of ice. Indeed it is possible to use Eqn (2) to simulate the radar-wave velocity from, for instance, a fictive mixture composed of stable volumetric contents of debris $(47.5 \%)$ and air (5\%) and in which the ice (with an initial maximum content of $47.5 \%$, corresponding to a situation of pore ice in excess) is progressively replaced by water. This leads us to consider that in such a medium radarwave velocities decreasing as low as $0.06-0.07 \mathrm{~m} \mathrm{~ns}^{-1}$ can occur while ice is present in the ground in small quantity ( 10\%).

Previous geophysical studies have already reported the possibility of encountering considerable amounts of water in rock glaciers (Croce and Milana, 2002; Musil and others, 2006; Hauck and others, 2011). Arenson and others (2002) reported that during drillings into the Murtèl-Corvatsch rock glacier, Switzerland, water was found at the permafrost table but also at greater depths inside the permafrost body. The hydrology of rock glaciers is known to be complex (Burger and others, 1999). Conceptual models of rock glacier hydrology have usually considered the permafrost core in rock glaciers as an impermeable body with water flowing rapidly over it through the superficial active layer (suprapermafrost flow) and more slowly below it (sub-permafrost flow) (Giardino and others, 1992; Burger and others, 1999; Williams and others, 2006). Using dye-tracing experiments, Tenthorey $(1992,1994)$ also deduced the existence of water flowing through an inactive rock glacier ('intra-flow'), with no supra-permafrost flow, a phenomenon that was attributed to the ice-poor nature of the material and the occurrence of thermokarst subsidence within the rock glacier. The conceptual model of Tenthorey (1992, 1994) included water transfer from the active layer down the rock glacier through unfrozen channels. Our interpretation of GPR-derived locally high water content in our studied rock glacier is in agreement with these observations and models. The occurrence of unfrozen water within the rock glacier is also compatible with the constant zero-curtain effect observed in the ground temperatures and which may indeed express permafrost degradation in the rock glacier. The idea of a melting structure with water at near-melting-point temperature and percolating at depth is further supported by the poor state of the core samples encountered below 19-20 m depth in borehole DDH2010-1.

Finally, the generally high velocities $\left(0.15-0.17 \mathrm{~m} \mathrm{~ns}^{-1}\right)$ observed in the first few meters of the structure (active layer of the rock glacier) must be explained by the larger volumes of air within the layer. For example, if we consider the active layer to be devoid of unfrozen water and ice, a velocity of 
$0.16 \mathrm{~m} \mathrm{~ns}^{-1}$ yields an air content of $22 \%$ using Eqn (2). The special case of the lower velocity $\left(0.13 \mathrm{~m} \mathrm{~ns}^{-1}\right)$ in the active layer of the CMP1 profile has to be explained by the finer materials (likely to retain water) observed in the core samples from the drilling.

\subsection{GPR stratigraphy and rock glacier development}

The prominent bounding reflectors encountered at depth in both the longitudinal and transversal profiles of the rock glacier are interpreted as the basal contact between the rock glacier and the underlying sediments or bedrock. They give an approximation of the rock glacier thickness. The latter varies between $10 \mathrm{~m}$ in its upper part, close to the talus slopes, and $30 \mathrm{~m}$ or even more in its lower part. The poor imaging of the GPR data in the areas affected by mining operations prevents a more precise estimation. The reduced GPR imaging in the areas affected by mining (construction of platforms and later infilling by mining waste rocks) is still poorly understood. It may result from an increase in the material conductivity due to compaction of the materials (Johnson and others, 2001) and thus increased attenuation of the radar signal, and from the disruption of the stratigraphy due to operation of machinery and the overburden pressure of the waste rocks, as suggested by the stratigraphy (disorganization, folded structure) in the lower part of QNW4. In areas where the original structure is clearly visible, the rather smooth stratigraphy together with the steady surface topography supports the idea of a rock glacier that has undergone somewhat more extensive than compressive deformations during flow. The stacked, mostly concordant and quite laterally - along longitudinal profiles and also to some extent along the transversal profile continuous GPR layers of the rock glacier could be regarded as contradicting the lateral variations of the radar-wave velocity. In fact, the lateral variations of the radar-wave velocity appear more as punctual discontinuities than a continuously irregular phenomenon; furthermore, they were only highlighted along a transversal axis (QNW5) and not along longitudinal profiles. Thus, the GPR stratigraphy tends to suggest a sequential development of the landform. The apparently heterogeneous vertical distribution of ice further supports this scenario. In the hypothesis that little ice was lost during the retrieval of core samples from the boreholes, the structure of the studied rock glacier appears as a succession of layers alternatively poor and rich in pore ice. Pore ice within rock glaciers can originate from refreezing of rain- or meltwater percolating from the surface, groundwater seepage from upslope, or snow burial (Haeberli and Mühll, 1996; Haeberli and others, 2006). Below steep slopes the origin of snow can be avalanches, as highlighted in arctic regions (Humlum and others, 2007). Hence the ice-poor layers may represent dry periods with limited or no formation of pore ice, while the ice-rich layers may represent wet periods with enhanced formation of pore ice. Avalanche maps for the mine area indicate important avalanche activity on the southwest-facing slopes of Quebrada NW, which suggests that snow avalanching and consequent snow burial is likely to be an important process for the formation of interstitial ice in the rock glaciers in Quebrada NW.

\section{CONCLUSION}

We have presented a unique combination of sediment cores, ground temperature records and GPR data collected on a small valley-side rock glacier in Quebrada NW in the semiarid Andes of Chile. Particular attention was paid to the analysis and processing of the GPR data in order to derive the distribution of the radar-wave velocity and reconstruct the GPR stratigraphy. The combined analysis of these data provides information on the inner structure and materials of the rock glacier. Our study has led to the following conclusions: (1) the rock glacier is a permafrost landform with a thermal state close to the melting point. Given the average air temperature registered at the site $\left(+0.5^{\circ} \mathrm{C}\right)$, the observed zero curtain is thought to reflect current permafrost degradation; (2) the rock glacier is up to $30 \mathrm{~m}$ thick toward its terminus, though uncertainty remains in the lower intervened parts where the GPR signal was strongly attenuated; (3) the rock glacier is a layered landform with vertical alternations between ice-poor and ice-rich layers, where the extracted ice content varies between $15 \%$ and $30 \%$; (4) in line with the near-melting thermal regime, the occurrence of low radar-wave velocities in various locations within the rock glacier suggests that water stagnates or circulates through the pores of the structure and through possible conduits in the permafrost, adding to the evidence that the permafrost in the rock glacier is currently degrading. Future works on this site will aim to improve the geophysical mapping of the internal structure by combining different geophysical methods and more advanced modeling of the geophysical properties.

\section{ACKNOWLEDGEMENTS}

This study was funded by Minera Los Pelambres (MLP) through research contract CS-581. The MLP Company was informed of the content of the manuscript but did not interfere in its production. We thank the partners at MLP for providing technical and logistic support during the field surveys. Roberto Garrido, Jorge Marín and Rodrigo Sáez provided assistance during field campaigns and with the processing of remote-sensing and GIS data. We thank Christian Camerlynck and Fayçal Rejiba for advice on the processing of GPR data. We also thank Helmut Hausmann and an anonymous reviewer for valuable and constructive comments on the manuscript.

\section{REFERENCES}

Abid MM (2005) Spacecraft sensors. Wiley, Chichester

Angillieri MYE (2009) A preliminary inventory of rock glaciers at $30^{\circ} \mathrm{S}$ latitude, Cordillera Frontal of San Juan, Argentina. Quat. Int., 195(1-2), 151-157 (doi: 10.1016/j.quaint.2008.06.001)

Annan AP (2003) Ground penetrating radar: principles, procedures and applications. Sensors and Software Inc., Mississauga, Ont.

Arenson LU (2002) Unstable Alpine permafrost: a potentially important natural hazard - variations of geotechnical behaviour with time and temperature. (PhD thesis, ETH Zürich)

Arenson LU and Jakob M (2010) The significance of rock glaciers in the dry Andes - a discussion of Azócar and Brenning (2010) and Brenning and Azócar (2010). Permafrost Periglac. Process., 21(3), 282-285 (doi: 10.1002/ppp.693)

Arenson LU and Springman SM (2005) Triaxial constant stress and constant strain rate tests on ice-rich permafrost samples. Can. Geotech. J., 42(2), 412-430 (doi: 10.1139/t04-111)

Arenson L, Hoelzle M and Springman S (2002) Borehole deformation measurements and internal structure of some rock glaciers in Switzerland. Permafrost Periglac. Process., 13(2), 117-135 (doi: 10.1002/ppp.414) 
Azócar G and Brenning A (2008) Intervenciones de glaciares rocosos en minera Los Pelambres, región de Coquimbo, Chile. Tech. Rep. University of Waterloo, Waterloo, Ont.

Azócar GF and Brenning A (2010) Hydrological and geomorphological significance of rock glaciers in the dry Andes, Chile $\left(27-33^{\circ} \mathrm{S}\right)$. Permafrost Periglac. Process., 21(1), 42-53 (doi: 10.1002/ppp.669)

Barsch D (1996) Rockglaciers: indicators for the present and former geoecology in high mountain environments. (Springer Series in Physical Environment 16) Springer, Berlin

Barsch D, Fierz H and Haeberli W (1979) Shallow core drilling and borehole measurements in the permafrost of an active rock glacier near the Grubengletscher, Wallis, Swiss Alps. Arct. Alp. Res., 11(2), 215-228

Bastida E (2006) Sustainable investment in the minerals sector: reexamining the paradigm. EconPapers, 6(4), 401-406 (doi: 10.1007/s10784-006-9019-x)

Bastida E, Irarrázabal R and Labó R (2005) Mining investment and policy developments: Argentina, Chile and Peru. CEPMLP Internet J., 16, Article 10. http://www.dundee.ac.uk/cepmlp/ journal/html/Vol16/Vol16_10.pdf

Berthling I (2011) Beyond confusion: rock glaciers as cryoconditioned landforms. Geomorphology, 131(3-4), 98-106 (doi: 10.1016/j.geomorph.2011.05.002)

Birchak RR, Gardner GC, Hipp JE and Victor JM (1974) High dielectric constant microwave probes for sensing soil moisture. IEEE Proc., 62(1), 93-98 (doi: 10.1109/PROC.1974.9388)

Bittelli M, Flury M and Roth K (2004) Use of dielectric spectroscopy to estimate ice content in frozen porous media. Water Resour. Res., 40(W4), W04212 (doi: 10.1029/2003WR002343)

Bradford JH (2008) Measuring water content heterogeneity using multifold GPR with reflection tomography. Vadose Zone J., 7, 184-193 (doi: 10.2136/vzj2006.0160)

Bradford JH, Nichols J, Mikesell TD and Harper JT (2009) Continuous profiles of electromagnetic wave velocity and water content in glaciers: an example from Bench Glacier, Alaska, USA. Ann. Glaciol., 50(51), 1-9 (doi: 10.3189/ 172756409789097540)

Brandt O, Langley K, Kohler J and Hamran S-E (2007) Detection of buried ice and sediment layers in permafrost using multifrequency ground-penetrating radar: a case examination on Svalbard. Remote Sens. Environ., 111(2-3), 212-227 (doi: 10.1016/j.rse.2007.03.025)

Brenning A (2005) Climatic and geomorphological controls of rock glaciers in the Andes of central Chile: combining statistical modelling and field mapping. (PhD thesis, Humboldt-Universität zu Berlin)

Brenning A (2010) The significance of rock glaciers in the dry Andes - reply to L. Arenson and M. Jakob. Permafrost Periglac. Process., 21(3), 286-288 (doi: 10.1002/ppp.702)

Brenning A and Azócar GF (2010) Minería y glaciares rocosos: impactos ambientales, antecedentes políticos y legales, y perspectivas futuras. Rev. Geogr. Norte Grande, 47, 143-158

Burger KC, Degenhardt JJJ and Giardino JR (1999) Engineering geomorphology of rock glaciers. Geomorphology, 31(1-4), 93-132 (doi: 10.1016/S0169-555X(99)00074-4)

Campbell MJ and Ulrichs J (1969) Electrical properties of rocks and their significance for lunar radar observations. J. Geophys. Res., 74(25), 5867-5881 (doi: 10.1029/JB074i025p05867)

Centro de Estudios Avanzadas en Zonas Áridas (CEAZA) (2012) Monitoreo de los glaciares rocosos en la Quebrada NW, aréa de la Mina Los Pelambres (MLP). Unpublished report

Croce FA and Milana JP (2002) Internal structure and behaviour of a rock glacier in the arid Andes of Argentina. Permafrost Periglac. Process., 13(4), 289-299 (doi: 10.1002/ppp.431)

Degenhardt JJJ (2009) Development of tongue-shaped and multilobate rock glaciers in alpine environments - interpretations from ground-penetrating radar surveys. Geomorphology, 109(3-4), 94-107 (doi: 10.1016/j.geomorph. 2009.02.020)
Degenhardt JJJ, Giardino JR and Junck MB (2003) GPR survey of a lobate rock glacier in Yankee Boy Basin, Colorado, USA. In Bristow CS and Jol HM eds. Ground-penetrating radar in sediments. (Special Publication 211) Geological Society, London

Delleur JW (1999) The handbook of groundwater engineering. CRC Press/Springer, Boca Raton, FL/Heidelberg

DISSAM Sécurité (2002) Estudio glaciar de roca, emplazamiento botadero. (Tech. Rep. 411) Unpublished report

Dix C (1955) Seismic velocities from surface measurements. Geophysics, 20(1), 68-86 (doi: 10.1190/1.1438126)

Drungil CEC, Abt K and Gish TJ (1989) Soil moisture determination in gravelly soils with time domain reflectometry. Trans. Am. Soc. Agric. Eng., 32(1), 177-180

Eisen O, Nixdorf U, Wilhelms F and Miller H (2002) Electromagnetic wave speed in polar ice: validation of the commonmidpoint technique with high-resolution dielectric-profiling and $\gamma$-density measurements. Ann. Glaciol., 34, 150-156 (doi: 10.3189/172756402781817509)

Geoblast SA (2009) Estudio geoeléctrico en zona de avalanchas, sector mina Los Pelambres. Unpublished report

Geoestudios Ltda (1998) Estudio de glaciares de roca en el área de la mina Los Pelambres. Unpublished report

Giardino JR, Vitek JD and DeMorett JL (1992) A model of water movement in rock glaciers and associated water characteristics. In Dixon JC and Abrahams AD eds. Periglacial geomorphology. Wiley, Chichester, 159-184

Haeberli W and Mühll DV (1996) On the characteristics and possible origins of ice in rock glacier permafrost. Z. Geomorph., 104, 43-57

Haeberli W, Huder J, Keusen HR, Pika J and Röthlisberger H (1988) Core drilling through rock glacier-permafrost. In Senneset K ed. Proceedings of the 5th International Conference on Permafrost, 2-5 August 1988, Trondheim, Norway, Vol. 2. Tapir Publishers, Trondheim, 937-942

Haeberli W and 10 others (2006) Permafrost creep and rock glacier dynamics. Permafrost Periglac. Process., 17(3), 189-214 (doi: 10.1002/ppp.561)

Hanson S and Hoelzle M (2004) The thermal regime of the active layer at the Murtèl rock glacier based on data from 2002. Permafrost Periglac. Process., 15(3), 273-282 (doi: 10.1002/ ppp.499)

Hauck C, Böttcher M and Maurer H (2011) A new model for estimating subsurface ice content based on combined electrical and seismic data sets. Cryosphere, 5(2), 453-468 (doi: 10.5194/ tc-5-453-2011)

Hausmann H, Krainer K, Brückl E and Mostler W (2007) Internal structure and ice content of Reichenkar rock glacier (Stubai Alps, Austria) assessed by geophysical investigations. Permafrost Periglac. Process., 18(4), 351-367 (doi: 10.1002/ ppp.601)

Humlum O, Christiansen HH and Juliussen H (2007) Avalanchederived rock glaciers in Svalbard. Permafrost Periglac. Process., 18(1), 75-88 (doi: 10.1002/ppp.580)

International Copper Study Group (ICSG) (2010) The world copper factbook 2010. International Copper Study Group, Lisbon http://www.icsg.org

Johnson CK, Doran JW, Duke HR, Wienhold BJ, Eskridge KM and Shanahan JF (2001) Field-scale electrical conductivity mapping for delineating soil condition. Soil Sci. Soc. Am. J., 65(6), 18291837 (doi: 10.2136/sssaj2001.1829)

Jol HM (2009) Ground-penetrating radar theory and applications. Elsevier Science, Amsterdam

Lehmann F and Green AG (2000) Topographic migration of georadar data: implications for acquisition and processing. Geophysics, 65(3), 836-848 (doi: 10.1190/1.1444781)

Leopold M, Williams MW, Caine N, Völkel J and Dethier D (2011) Internal structure of the Green Lake 5 rock glacier, Colorado Front Range, USA. Permafrost Periglac. Process., 22(2), 107-119 (doi: 10.1002/ppp.706) 
Marangunic C (2010) Physical characteristics of rock glaciers in the mountains of central Chile. International Glaciological Conference on Ice and Climate Change: A View from the South, 1-3 February 2010, Valdivia, Chile. http://www.geostudias.cl/ esp/archivos.php?tipo $=3$

Maurer H and Hauck C (2007) Geophysical imaging of alpine rock glaciers. J. Glaciol., 53(180), 110-120 (doi: 10.3189/ 172756507781833893)

Milana JP and Güell A (2008) Diferencias mecánicas e hídricas del permafrost en glaciares de rocas glacigénicos y criogénicos, obtenidas de datos sísmicos en El Tapado, Chile. Rev. Asoc. Geol. Argentina, 63(3), 310-325

Monnier S, Camerlynck C and Rejiba F (2008) Ground-penetrating radar survey and stratigraphic interpretation of the Plan du Lac rock glaciers, Vanoise Massif, northern French Alps. Permafrost Periglac. Process., 19(1), 19-30 (doi: 10.1002/ppp.610)

Monnier S, Camerlynck C, Fejiba F, Kinnard C, Feuillet T and Dhemaied A (2011) Structure and genesis of the Thabor rock glacier (northern French Alps) determined from morphological and ground-penetrating radar surveys. Geomorphology, 134(3-4), 269-279 (doi: 10.1016/j.geomorph.2011.07.004)

Moore JC and 8 others (1999) High-resolution hydrothermal structure of Hansbreen, Spitsbergen, mapped by groundpenetrating radar. J. Glaciol., 45(151), 524-532

Moorman BJ (2005) Glacier-permafrost hydrological interconnectivity: Stagnation Glacier, Bylot Island, Canada. In Harris $\mathrm{C}$ and Murton JB eds. Cryospheric systems: glaciers and permafrost. (Special Publication 242) Geological Society, London, 63-74

Musil M, Maurer HR, Holliger K and Green AG (2006) Internal structure of an alpine rock glacier based on crosshole georadar traveltimes and amplitudes. Geophys. Prospect., 54(3), 273-285 (doi: 10.1111/j.1365-2478.2006.00534.x)

Noborio K (2001) Measurement of soil water content and electrical conductivity by time domain reflectometry: a review. Comput. Electron. Agr., 31(3), 213-237 (doi: 10.1016/S01681699(00)00184-8)

Outcalt SI, Nelson FE and Hinkel KM (1990) The zero-curtain effect: heat and mass transfer across an isothermal region in freezing soil. Water Resour. Res., 26(7), 1509-1516 (doi: 10.1029/WR026i007p01509)

Palmer MA and 11 others (2010) Mountaintop mining consequences. Science, 327(5962), 148-149 (doi: 10.1126/science.1180543)
Schrott L (1996) Some geomorphological-hydrological aspects of rock glaciers in the Andes (San Juan, Argentina). Z. Geomorph., 104, 161-173

Sillitoe RH (2010) Porphyry copper systems. Econ. Geol., 105(1), 3-41 (doi: 10.2113/gsecongeo.105.1.3)

Smith MW and Patterson DE (1984) Determining the unfrozen water content in soils by time-domain reflectometry. Atmos.-Ocean, 22(2), 261-263 (doi: 10.1080/07055900.1984.9649198)

Stolt RH (1978) Migration by Fourier transform. Geophysics, 43(1), 23-48 (doi: 10.1190/1.1440826)

Tenthorey G (1992) Perennial névés and the hydrology of rock glaciers. Permafrost Periglac. Process., 3(3), 247-252 (doi: 10.1002/ppp.3430030313)

Tenthorey G (1994) Hydrologie liée aux glaciers rocheux, Hout-Val de Réchy (Nax, VS). Bull. Murith., 112,97-116

Thomson LI, Osinski GR and Pollard WH (2012) The dielectric permittivity of terrestrial ground ice formations: considerations for planetary exploration using ground-penetrating radar. J. Geophys. Res., 117(E9), E09003 (doi: 10.1029/2012JE004053)

Topp GC, Davis JL and Annan AP (1980) Electromagnetic determination of soil water content: measurements in coaxial transmission lines. Water Resour. Res., 16(3), 574-582 (doi: 10.1029/WR016i003p00574)

Trombotto D, Buk E and Hernández J (1999) Rock glaciers in the Southern Central Andes (appr. $33^{\circ}$ S.L.) Mendoza, Argentina: a review. Bamberger Geogr. Schrift. 19. Selbstverlag des Faches Geographie an der Universität Bamberg, Bamberg, 145-173

Van Everdingen RO ed. (2005) Multi-language glossary of permafrost and related ground-ice terms. National Snow and Ice Data Center/World Data Center for Glaciology, Boulder, CO

Washburn AL (1979) Geocryology: a survey of periglacial processes and environments. Edward Arnold, London

Williams MW, Knauf M, Caine N, Liu F and Verplanck PL (2006) Geochemistry and source waters of rock glacier outflow, Colorado Front Range. Permafrost Periglac. Process., 17(1), 13-33 (doi: 10.1002/ppp.535)

Yilmaz Ö and Doherty SM (2001) Seismic data analysis: processing, inversion and interpretation of seismic data. (Investigations in Geophysics 10) Society of Exploration Geophysicists, Tulsa, OK

Zakri T, Laurent J-P and Vauclin M (1998) Theoretical evidence for 'Lichtenecker's mixture formulae' based on the effective medium theory. J. Phys. D, 31(3), 1589 (doi: 10.1088/0022$3727 / 31 / 13 / 013)$ 